\title{
Planococcus maritimus sp. nov., isolated from sea water of a tidal flat in Korea
}

\author{
Correspondence \\ Yong-Ha Park \\ yhpark@kribb.re.kr
}

\author{
Jung-Hoon Yoon, ${ }^{1}$ Norbert Weiss, ${ }^{2}$ Kook Hee Kang, ${ }^{3}$ Tae-Kwang Oh ${ }^{1}$ \\ and Yong-Ha Park ${ }^{1,4}$ \\ ${ }^{1}$ Korea Research Institute of Bioscience and Biotechnology (KRIBB), PO Box 115, Yusong, \\ Taejon, Korea \\ ${ }^{2}$ DSMZ - Deutsche Sammlung von Mikroorganismen und Zellkulturen, Mascheroder Weg $1 \mathrm{~b}$, \\ D-38124 Braunschweig, Germany \\ ${ }^{3}$ Department of Food and Life Science, Sungkyunkwan University, Chunchun-dong 300, \\ Jangan-gu, Suwon, Korea \\ ${ }^{4}$ National Research Laboratory of Molecular Ecosystematics, Institute of Probionic, Probionic \\ Corporation, Bio-venture Centre, KRIBB, PO Box 115, Yusong, Taejon, Korea
}

Two Gram-positive, motile cocci, strains TF- $9^{\top}$ and TF-16, were isolated from sea water of a tidal flat in Korea. Phylogenetic analysis based on 16S rDNA sequences showed that the strains fall within the radiation of the cluster comprising Planococcus citreus and Planococcus kocurii, and this cluster joined the clade comprising Planomicrobium species and Planococcus alkanoclasticus and Planococcus psychrophilus with a high bootstrap resampling value. Strains TF- $9^{\top}$ and TF-16 contained MK-8, MK-7 and MK- 6 as the predominant menaquinones. The major fatty acid was anteiso- $C_{15: 0}$. The DNA G $+C$ contents of strains TF- $9^{\top}$ and TF-16 were respectively 48 and $49 \mathrm{~mol} \%$. The level of $16 \mathrm{~S}$ rDNA identity between strains TF- $9^{\top}$ and TF-16 was $98.9 \%$. Strain TF- $9^{T}$ and TF-16 respectively exhibited levels of $16 \mathrm{~S}$ rDNA identity of $97 \cdot 2-98 \cdot 4$ and 96.9-99.5\% to the type strains of Planococcus kocurii, Planococcus citreus and Planococcus antarcticus. The mean level of DNA-DNA relatedness between strains TF- $9^{\top}$ and TF-16 was $36 \cdot 7 \%$. Strains TF- $9^{\top}$ and TF-16 respectively exhibited levels of DNA-DNA relatedness of $7 \cdot 1-43 \cdot 4$ and $3 \cdot 5-80 \cdot 9 \%$ to Planococcus citreus DSM $20549^{\top}$, Planococcus kocurii DSM $20747^{\top}$ and Planococcus antarcticus DSM $14505^{\top}$. On the basis of the phenotypic, phylogenetic and genomic data, strain TF- $9^{\top}\left(=\mathrm{KCCM} 41587^{\top}=\mathrm{JCM} 11543^{\top}\right)$ should be placed as a novel species of the genus Planococcus, for which the name Planococcus maritimus sp. nov. is proposed, and strain TF-16 should be classified as a member of Planococcus citreus.

The genus Planococcus was first proposed by Migula (1894) to accommodate motile cocci. However, the name Planococcus was not validly published for many years. The first species, Planococcus citreus, was proposed by Kocur et al. (1970) and the second, Planococcus kocurii, was proposed by Hao \& Komagata (1985). Two further species, Planococcus okeanokoites (Nakagawa et al., 1996) and Planococcus momeekinii (Junge et al., 1998), were then added to the

Published online ahead of print on 1 August 2003 as DOI 10.1099/ ijs.0.02557-0.

Abbreviation: ITS, internally transcribed spacer.

The GenBank accession numbers for the 16S rDNA sequences of strains TF-9 ${ }^{T}$ and TF-16 are respectively AF500007 and AF500008 and for the 16S-23S rDNA ITS sequences of strains TF- $9^{\top}$ and TF-16 they are AF500009 and AF500010.

Detailed results of DNA-DNA relatedness experiments are available as supplementary material in IJSEM Online. genus. Recently, on the basis of some differential taxonomic data, the latter two species were transferred to a new genus Planomicrobium, which was created with the newly isolated strain Planomicrobium koreense JG-07 ${ }^{\mathrm{T}}$ (Yoon et al., 2001). Subsequently, three more Planococcus species have been described: Planococcus alkanoclasticus (Engelhardt et al., 2001), Planococcus antarcticus and Planococcus psychrophilus (Reddy et al., 2002). In this study, we describe two bacterial strains, TF- $9^{\mathrm{T}}$ and TF-16, isolated from sea water of a tidal flat of the Yellow Sea in Korea. The two strains were found to be phylogenetically related to the genera Planococcus and Planomicrobium. Accordingly, the aim of the present study was to determine the exact taxonomic positions of strains TF- ${ }^{\mathrm{T}}$ and TF-16 with a combination of phenotypic properties, phylogeny based on $16 \mathrm{~S}$ rDNA sequence and genomic relatedness.

Strains TF-9 ${ }^{\mathrm{T}}$ and TF-16 were isolated by the dilution 
plating technique on marine agar 2216 (MA) (Difco) at $30{ }^{\circ}$ C. Planococcus citreus DSM $20549^{\mathrm{T}}$, Planococcus kocurii DSM $20747^{\mathrm{T}}$ and Planococcus antarcticus DSM $14505^{\mathrm{T}}$ were used as reference strains for some analyses. Cell biomass of strains TF- $9^{\mathrm{T}}$ and TF-16 for menaquinone and cell-wall analyses and for DNA extraction was obtained from marine broth 2216 (MB) (Difco) cultures at $30^{\circ} \mathrm{C}$. Cell biomass for polar lipid analysis was produced in a liquid medium (IFO medium no. 326) that contained $\left(1^{-1}\right) 10 \mathrm{~g}$ peptone, $2 \mathrm{~g}$ yeast extract, $1 \mathrm{~g} \mathrm{MgSO} 4.7 \mathrm{H}_{2} \mathrm{O}$ and $30 \mathrm{~g} \mathrm{NaCl}$. For fatty acid methyl ester (FAME) analysis, cell mass of strains TF-9 $9^{\mathrm{T}}$ and TF-16 was obtained from agar plates after 2 days cultivation at $30^{\circ} \mathrm{C}$ on MA.

Flagellation was examined with transmission electron microscopy using cells from an exponentially growing culture as described previously (Yoon et al., 2001). Gram reaction was determined using the bioMérieux Gram Stain kit according to the manufacturer's instructions. Catalase and oxidase activities were determined as described by Cowan \& Steel (1965) after cultivation for 3 days. Hydrolysis of casein, starch and Tween 80 and production of urease was determined as described by Cowan \& Steel (1965). Hydrolysis of aesculin and nitrate reduction were determined as described previously (Lanyi, 1987). Hydrolysis of hypoxanthine, tyrosine and xanthine was performed on MA plates with concentration of substrates described previously (Cowan \& Steel, 1965). Hydrolysis of gelatin was studied as by Cowan \& Steel (1965) with the modification that artificial sea water was used. The artificial sea water contained $\left(1^{-1}\right.$ distilled water) $23.6 \mathrm{~g} \mathrm{NaCl}, 0.64 \mathrm{~g} \mathrm{KCl}$, $4.53 \mathrm{~g} \mathrm{MgCl}_{2} \cdot 6 \mathrm{H}_{2} \mathrm{O}$, 5.94 g $\mathrm{MgSO}_{4} \cdot 7 \mathrm{H}_{2} \mathrm{O}$ and $1.3 \mathrm{~g}$ $\mathrm{CaCl}_{2} .2 \mathrm{H}_{2} \mathrm{O}$ (Levring, 1946). Acid production from carbohydrates was determined as described by Leifson (1963). Other characteristics were investigated as described by Yoon et al. (2003).

Preparation of cell walls and determination of peptidoglycan structure were carried out by the methods described by Schleifer \& Kandler (1972), with the modification that TLC on cellulose sheets was used instead of paper chromatography. Menaquinones were analysed as described previously (Komagata \& Suzuki, 1987) using reversedphase HPLC. For quantitative analysis of cellular fatty acid compositions, a loop of cell mass was harvested and FAMEs were prepared and identified following the instructions of the Microbial Identification System (MIDI). Polar lipids were extracted using the procedures described by Minnikin et al. (1984) and identified by two-dimensional TLC followed by spraying with appropriate detection reagents (Komagata \& Suzuki, 1987). Chromosomal DNA was isolated and purified according to the method described previously (Yoon et al., 1996), with the exception that ribonuclease $\mathrm{T} 1$ was used together with ribonuclease A. The $\mathrm{G}+\mathrm{C}$ content was determined by the method of Tamaoka \& Komagata (1984). DNA was hydrolysed and the resultant nucleotides were analysed by reversed-phase HPLC.
$16 \mathrm{~S}$ rDNA was amplified by PCR using two universal primers as described previously (Yoon et al., 1998). Sequencing of the amplified 16S rDNA and phylogenetic analysis were performed as described by Yoon et al. (2003). Sequencing of the 16S-23S rDNA internally transcribed spacer (ITS) was performed as described previously (Yoon et al., 1997). DNA-DNA hybridization was performed fluorometrically by the method of Ezaki et al. (1989) using photobiotin-labelled DNA probes and microdilution wells. Hybridization was performed with five replications for each sample. Of the values obtained, the highest and lowest values in each sample were excluded and the mean of the remaining three values was used as the DNA relatedness value.

Morphological, physiological and biochemical characteristics are given in Table 1 or the species description. The cell wall of strains TF- ${ }^{\mathrm{T}}$ and TF-16 contained the amino acids lysine, glutamic acid and alanine. Accordingly, the peptidoglycan type of strains TF- $9^{\mathrm{T}}$ and TF-16 was $\mathrm{A} 4 \alpha$, based on L-Lys-D-Glu, as described by Schleifer \& Kandler (1972). The menaquinones detected in strains TF- $9^{\mathrm{T}}$ and TF-16 were MK-8 (54 and 54\%, respectively), MK-7 (28 and $25 \%$ ) and MK-6 (18 and $21 \%$ ). Strains TF-9 ${ }^{\mathrm{T}}$ and TF-16 contained anteiso- $\mathrm{C}_{15: 0}$ as the major fatty acid and significant amounts of iso- $\mathrm{C}_{16: 0}$ and iso- $\mathrm{C}_{14: 0}$ (Table 2). The cellular phospholipids found in strains TF-9 ${ }^{\mathrm{T}}$ and TF-16 were phosphatidylethanolamine, phosphatidylglycerol and diphosphatidylglycerol. The genomic DNA G + C contents of strains $\mathrm{TF}-9^{\mathrm{T}}$ and TF-16 were respectively 48 and $49 \mathrm{~mol} \%$.

The 16S rDNA sequences of strains TF-9 ${ }^{\mathrm{T}}$ and TF-16 determined in this study respectively comprised 1507 and 1506 nucleotides, representing $96 \%$ of the Escherichia coli $16 \mathrm{~S}$ rRNA sequence. Phylogenetic analyses based on three tree-making algorithms showed that strains TF- $9^{\mathrm{T}}$ and TF-16 fall within the evolutionary radiation enclosed by the genus Planococcus (a neighbour-joining tree is shown in Fig. 1). The level of $16 \mathrm{~S}$ rDNA identity between strains TF- $9^{\mathrm{T}}$ and TF-16 was $98 \cdot 9 \%$. Strains TF- $9^{\mathrm{T}}$ and TF-16 respectively exhibited levels of $16 \mathrm{~S}$ rDNA identity of $97 \cdot 2-$ $98 \cdot 4$ and $96 \cdot 9-99 \cdot 5 \%$ to the type strains of Planococcus citreus, Planococcus kocurii and Planococcus antarcticus. Strains TF- ${ }^{\mathrm{T}}$ and TF-16 exhibited levels of $16 \mathrm{~S}$ rDNA identity of $96 \cdot 8-97 \cdot 4 \%$ to the type strains of Planococcus alkanoclasticus and Planococcus psychrophilus and of 97.4$98.0 \%$ to the type strains of Planomicrobium species. The 16S-23S ITS regions of strains TF- $9^{\mathrm{T}}$ and TF-16 were respectively 188 and 185 bp long. Strain TF- $9^{\mathrm{T}}$ exhibited levels of 16S-23S ITS identity of 94.5 and $78.5 \%$ to Planococcus citreus DSM $20549^{\mathrm{T}}$ and Planococcus kocurii DSM $20747^{\mathrm{T}}$, respectively, and strain TF-16 exhibited levels of 16S-23S ITS identity of 100 and $81.6 \%$ to Planococcus citreus DSM $20549^{\mathrm{T}}$ and Planococcus kocurii DSM $20747^{\mathrm{T}}$. Strains $\mathrm{TF}-\mathrm{9}^{\mathrm{T}}$ and TF-16 exhibited two independent levels of DNA-DNA relatedness of $37 \cdot 0$ and $36 \cdot 3 \%$. Levels of DNA-DNA relatedness between strain 
Table 1. Differential phenotypic properties of strains TF-9 ${ }^{\top}$ and TF-16 and Planococcus species

Strain/species: 1, strain TF-9 ${ }^{\mathrm{T}}$; 2, strain TF-16; 3, Planococcus citreus (data from Hao \& Komagata, 1985); 4, Planococcus kocurii (Hao \& Komagata, 1985); 5, Planococcus antarcticus (Reddy et al., 2002). +, Positive; -, negative; V, variable; ND, not determined. All strains or species are cocci and are positive for Gram stain, motility, catalase and growth in the absence of NaCl. All strains or species are negative for spore formation, oxidase, urease, nitrate reduction, hydrolysis of aesculin and starch and acid production from D-cellobiose and lactose.

\begin{tabular}{|c|c|c|c|c|c|}
\hline Characteristic & 1 & 2 & 3 & 4 & 5 \\
\hline $15 \% \mathrm{NaCl}$ & + & + & + & - & - \\
\hline Max. temperature for growth $\left({ }^{\circ} \mathrm{C}\right)$ & 41 & 43 & ND & ND & 30 \\
\hline Hydrolysis of gelatin & + & - & + & $\mathrm{V}$ & + \\
\hline \multicolumn{6}{|l|}{ Acid production from: } \\
\hline D-Mannitol & + & - & - & - & ND \\
\hline Melibiose & - & + & - & - & ND \\
\hline Predominant menaquinones & MK-8, MK-7, MK-6 & MK-8, MK-7, MK-6 & MK-8, MK-7 & MK-8, MK-7 & MK-7, MK-8 \\
\hline DNA G $+\mathrm{C}$ content $(\mathrm{mol} \%)$ & 48 & 49 & $48-51$ & $40-43$ & 42 \\
\hline
\end{tabular}

TF-9 ${ }^{\mathrm{T}}$ and Planococcus citreus DSM $20549^{\mathrm{T}}$, Planococcus kocurii DSM $20747^{\mathrm{T}}$ and Planococcus antarcticus DSM $14505^{\mathrm{T}}$ were $7 \cdot 1-43 \cdot 4 \%$. Strain TF-16 exhibited levels of

Table 2. Cellular fatty acid profiles of strains $T F-9^{\top}$ and TF-16 and the type strains of Planococcus citreus and Planococcus kocurii

Strains: 1, TF-9 ${ }^{\mathrm{T}}$; 2, TF-16; 3, Planococcus citreus DSM $20549^{\mathrm{T}}$ (data from Yoon et al., 2001); 4, Planococcus kocurii DSM $20747^{\mathrm{T}}$ (Yoon et al., 2001). Values are percentages of total fatty acids. - , Not detected.

\begin{tabular}{|c|c|c|c|c|}
\hline Fatty acid & 1 & 2 & 3 & 4 \\
\hline \multicolumn{5}{|c|}{ Straight-chain fatty acids: } \\
\hline $\mathrm{C}_{15: 0}$ & $3 \cdot 1$ & $4 \cdot 0$ & $6 \cdot 7$ & $7 \cdot 2$ \\
\hline $\mathrm{C}_{16: 0}$ & $0 \cdot 8$ & $0 \cdot 7$ & - & $1 \cdot 4$ \\
\hline $\mathrm{C}_{17: 0}$ & $2 \cdot 5$ & $2 \cdot 2$ & $2 \cdot 3$ & - \\
\hline \multicolumn{5}{|l|}{ Branched fatty acids: } \\
\hline iso- $\mathrm{C}_{14: 0}$ & $13 \cdot 1$ & $21 \cdot 6$ & $8 \cdot 8$ & $13 \cdot 1$ \\
\hline iso- $\mathrm{C}_{15: 0}$ & $9 \cdot 5$ & $6 \cdot 4$ & - & $5 \cdot 1$ \\
\hline anteiso- $\mathrm{C}_{15: 0}$ & $30 \cdot 6$ & $26 \cdot 1$ & $52 \cdot 1$ & $40 \cdot 9$ \\
\hline iso- $\mathrm{C}_{16: 0}$ & $18 \cdot 5$ & $17 \cdot 7$ & $8 \cdot 1$ & $7 \cdot 2$ \\
\hline iso- $\mathrm{C}_{17: 0}$ & $3 \cdot 1$ & $1 \cdot 4$ & - & $1 \cdot 7$ \\
\hline anteiso- $\mathrm{C}_{17: 0}$ & $4 \cdot 4$ & $2 \cdot 6$ & $5 \cdot 2$ & $2 \cdot 6$ \\
\hline iso- $\mathrm{C}_{17: 1} \omega 10 c$ & $0 \cdot 8$ & $0 \cdot 5$ & - & $2 \cdot 5$ \\
\hline iso- $\mathrm{C}_{18: 0}$ & $2 \cdot 1$ & $1 \cdot 3$ & - & - \\
\hline \multicolumn{5}{|c|}{ Unsaturated fatty acids: } \\
\hline $\mathrm{C}_{16: 1} \omega 7 c$ alcohol & $8 \cdot 9$ & $13 \cdot 1$ & $9 \cdot 8$ & $11 \cdot 4$ \\
\hline $\mathrm{C}_{16: 1} \omega 11 c$ & $0 \cdot 7$ & $1 \cdot 1$ & $2 \cdot 5$ & $2 \cdot 5$ \\
\hline \multicolumn{5}{|l|}{ Hydroxy fatty acids: } \\
\hline $\mathrm{C}_{16: 0} 2-\mathrm{OH}$ & $0 \cdot 8$ & - & - & - \\
\hline Summed feature $4^{*}$ & $1 \cdot 3$ & $1 \cdot 3$ & $4 \cdot 5$ & $4 \cdot 5$ \\
\hline
\end{tabular}

${ }^{*}$ Summed feature 4 represents iso- $\mathrm{C}_{17: 1} \mathrm{I}$ and/or anteiso- $\mathrm{C}_{17: 1} \mathrm{~B}$, which could not be separated by GLC with the MIDI system.
DNA-DNA relatedness of $80.9 \%$ to Planococcus citreus DSM $20549^{\mathrm{T}}$ and $3 \cdot 5-5 \cdot 7 \%$ to Planococcus kocurii DSM $20747^{\mathrm{T}}$ and Planococcus antarcticus DSM $14505^{\mathrm{T}}$ (levels of DNA-DNA relatedness are available as supplementary material in IJSEM Online).

The genus Planococcus has recently been dissected into two genera, Planococcus and Planomicrobium, on the basis of menaquinone profiles and phylogenetic data as well as cellular morphology (Yoon et al., 2001). This classification indicates that cellular morphology may be important for determining the taxonomic status of organisms that are phylogenetically related to the genera Planococcus and Planomicrobium, although cells of Planomicrobium momeekinii are cocci or short rods in old cultures. Since the proposal of Yoon et al. (2001), the additional Planococcus species Planococcus alkanoclasticus, Planococcus antarcticus and Planococcus psychrophilus have been described (Engelhardt et al., 2001; Reddy et al., 2002). However, cells of Planococcus alkanoclasticus and Planococcus psychrophilus are rods, unlike other Planococcus species (Engelhardt et al., 2001; Reddy et al., 2002). Moreover, with the recent description of the genus Planomicrobium, it is apparent that Planococcus alkanoclasticus and Planococcus psychrophilus fall within the evolutionary radiation comprising Planomicrobium species, not Planococcus species (Engelhardt et al., 2001) (Fig. 1). This cluster joins the clade comprising Planococcus species with a high bootstrap resampling value (Engelhardt et al., 2001) (Fig. 1). Accordingly, it is very likely that Planococcus alkanoclasticus and Planococcus psychrophilus can be considered as members of the genus Planomicrobium.

Strains TF-9 ${ }^{\mathrm{T}}$ and TF-16 fall within the radiation of the cluster comprising Planococcus citreus, Planococcus kocurii and Planococcus antarcticus. This cluster was differentiated from the phylogenetic clade comprising Planomicrobium 


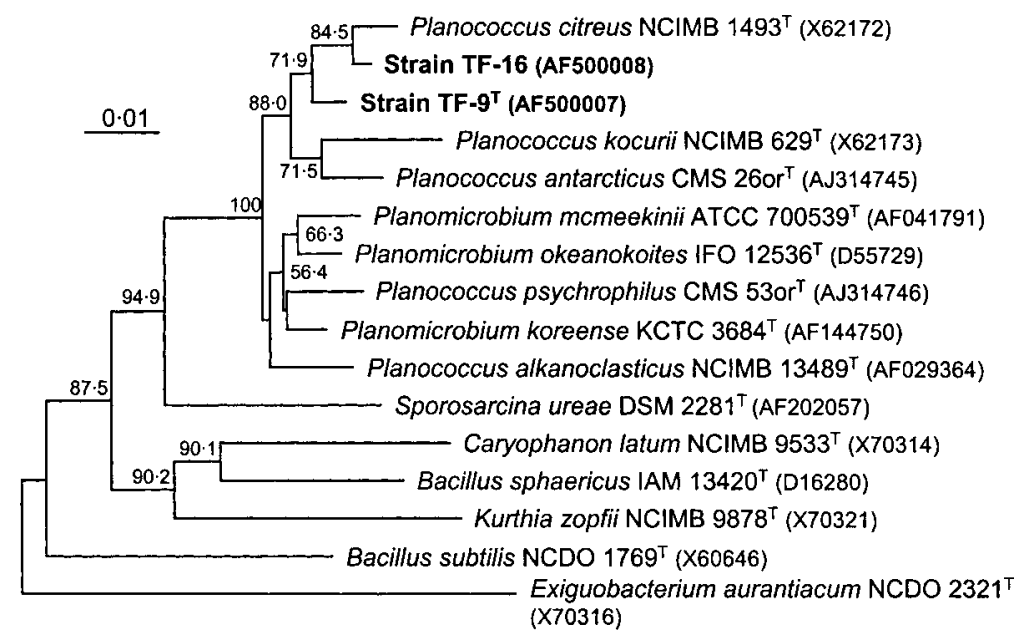

Fig. 1. Neighbour-joining tree based on $16 \mathrm{~S}$ rDNA sequences showing the positions of strains TF- $9^{\top}$ and TF-16, Planococcus species, Planomicrobium species and representatives of some other taxa. Bar, 0.01 substitutions per nucleotide position. Bootstrap values (expressed as percentages of 1000 replications) greater than $50 \%$ are shown at branch points.

species and Planococcus alkanoclasticus and Planococcus psychrophilus by a high bootstrap resampling value (Fig. 1). Cells of strains TF- $9^{\mathrm{T}}$ and TF-16 were observed to be cocci in all growth phases, as shown for Planococcus citreus, Planococcus kocurii and Planococcus antarcticus. The cellular fatty acid patterns of strains TF- $9^{\mathrm{T}}$ and TF-16 are similar to those of members of the genus Planococcus (Table 2). Strains TF- $9^{\mathrm{T}}$ and TF-16 have an identical cell-wall peptidoglycan type (L-Lys-D-Glu) to Planococcus species, whereas Planomicrobium species, except Planomicrobium koreense, have cell-wall peptidoglycan based on L-Lys-D-Asp (Yoon et al., 2001). Strains TF- $9^{\mathrm{T}}$ and TF-16 were found to have menaquinone profiles that differed slightly from those of Planococcus species (Yoon et al., 2001). The two strains are characterized by the predominance of MK-8, followed by MK-7 and MK-6, whereas Planococcus species have similar amounts of MK-7 and MK-8 (Hao \& Komagata, 1985). The menaquinone profile of strains TF- $9^{\mathrm{T}}$ and TF-16 is more similar to that of Planomicrobium koreense than those of Planococcus species (Yoon et al., 2001). Menaquinones may not be a key marker for differentiating the genera Planococcus and Planomicrobium. These data indicate that there is heterogeneity or cross-over in the properties of the genera Planococcus and Planomicrobium, e.g. the cellwall peptidoglycan type in Planomicrobium koreense and the menaquinone pattern in strains TF- $9^{\mathrm{T}}$ and TF-16. Accordingly, the primary evidence for differentiating the two genera appears to be morphology and phylogenetic analysis based on $16 \mathrm{~S}$ rDNA sequences.

Strains TF- $9^{\mathrm{T}}$ and TF-16 are similar in most morphological and physiological characteristics except some properties such as acid production from carbohydrates and temperature for growth (Table 1). There are 16 nucleotide differences $(1 \cdot 1 \%$ difference) in the $16 \mathrm{~S} \mathrm{rDNA}$ sequences of strains TF- $9^{\mathrm{T}}$ and TF-16 (Fig. 1). The DNA relatedness between the two strains is less than $70 \%$, indicating a level of DNA relatedness appropriate for defining a species in current bacterial systematics (Wayne et al., 1987). Accordingly, strains TF- $9^{\mathrm{T}}$ and TF-16 are considered as members of different species of the genus Planococcus. The DNA-DNA relatedness result indicates that strain TF-16 belongs to Planococcus citreus. The 16S-23S ITS sequence analysis also supports a close genetic relatedness between strain TF-16 and Planococcus citreus. Strain TF- $9^{\mathrm{T}}$ is differentiated from Planococcus citreus and Planococcus kocurii as well as from strain TF- 16 by comparison of $16 \mathrm{~S}$ rDNA and 16S-23S ITS sequences. Levels of DNA-DNA relatedness provide decisive evidence that strain $\mathrm{TF}-9^{\mathrm{T}}$ is genetically different from Planococcus citreus, Planococcus kocurii and Planococcus antarcticus (Wayne et al., 1987). Therefore, on the basis of differences in some phenotypic characteristics and genetic distinctiveness, strain TF- ${ }^{\mathrm{T}}$ should be placed in the genus Planococcus as a novel species, for which the name Planococcus maritimus sp. nov. is proposed.

\section{Description of Planococcus maritimus sp. nov.}

Planococcus maritimus (ma.ri'ti.mus. L. masc. adj. maritimus living near the sea).

Cells are cocci, $1 \cdot 0-1 \cdot 4 \mu \mathrm{m}$ in diameter on MA. Motile by means of a single polar flagellum. Strictly aerobic. Colonies are smooth, glistening, low-convex, circular and yellow to orange in colour and $2 \cdot 0-3 \cdot 0 \mathrm{~mm}$ in diameter after 3 days cultivation at $30^{\circ} \mathrm{C}$ on MA. Growth occurs at 4 and $41{ }^{\circ} \mathrm{C}$ but not at above $42{ }^{\circ} \mathrm{C}$. Optimal growth temperature is $30^{\circ} \mathrm{C}$. Optimal $\mathrm{pH}$ for growth is $6 \cdot 0-8 \cdot 0$. Growth occurs weakly at $\mathrm{pH} 5 \cdot 0$ but not at $4 \cdot 5$. Grows in the presence of $0-17 \%(\mathrm{w} / \mathrm{v}) \mathrm{NaCl}$. Optimal growth occurs in the presence of $2 \%(\mathrm{w} / \mathrm{v}) \mathrm{NaCl}$. Casein is hydrolysed. Hypoxanthine, Tween 80 , tyrosine and xanthine are not hydrolysed. Acid is produced from D-fructose and D-ribose but not from adonitol, L-arabinose, D-galactose, maltose, D-mannose, D-melezitose, myo-inositol, D-raffinose, L-rhamnose, D-sorbitol, stachyose, sucrose, D-trehalose or D-xylose. The DNA G $+\mathrm{C}$ content of the type strain is $48 \mathrm{~mol} \%$. Other characteristics are given in Table 1.

The type strain, strain $\mathrm{TF}-9^{\mathrm{T}}\left(=\mathrm{KCCM} 41587^{\mathrm{T}}=\mathrm{JCM}\right.$ $11543^{\mathrm{T}}$ ), was isolated from sea water of a tidal flat of the Yellow Sea in Korea. 


\section{Acknowledgements}

This work was supported by the NRL research program (grants M10104000294-01J000012800 and M10104000294-01J000012811) and the 21C Frontier program of Microbial Genomics and Applications (grant MG02-0401-001-1-0-0) from the Ministry of Science and Technology (MOST) of the Republic of Korea.

\section{References}

Cowan, S. T. \& Steel, K. J. (1965). Manual for the Identification of Medical Bacteria. London: Cambridge University Press.

Engelhardt, M. A., Daly, K., Swannell, R. P. J. \& Head, I. M. (2001). Isolation and characterization of a novel hydrocarbon-degrading, Gram-positive bacterium, isolated from intertidal beach sediment, and description of Planococcus alkanoclasticus sp. nov. J Appl Microbiol 90, 237-247.

Ezaki, T., Hashimoto, Y. \& Yabuuchi, E. (1989). Fluorometric deoxyribonucleic acid-deoxyribonucleic acid hybridization in microdilution wells as an alternative to membrane filter hybridization in which radioisotopes are used to determine genetic relatedness among bacterial strains. Int J Syst Bacteriol 39, 224-229.

Hao, M. V. \& Komagata, K. (1985). A new species of Planococcus, $P$. kocurii isolated from fish, frozen foods, and fish curing brine. J Gen Appl Microbiol 31, 441-455.

Junge, K., Gosink, J. J., Hoppe, H.-G. \& Staley, J. T. (1998). Arthrobacter, Brachybacterium and Planococcus isolates identified from antarctic sea ice brine. Description of Planococcus momeekinii, sp. nov. Syst Appl Microbiol 21, 306-314.

Kocur, M., Páčová, Z., Hodgkiss, W. \& Martinec, T. (1970). The taxonomic status of the genus Planococcus Migula 1894. Int J Syst Bacteriol 20, 241-248.

Komagata, K. \& Suzuki, K. (1987). Lipids and cell-wall analysis in bacterial systematics. Methods Microbiol 19, 161-203.

Lanyi, B. (1987). Classical and rapid identification methods for medically important bacteria. Methods Microbiol 19, 1-67.

Leifson, E. (1963). Determination of carbohydrate metabolism of marine bacteria. J Bacteriol 85, 1183-1184.

Levring, T. (1946). Some culture experiments with Ulva and artificial seawater. Kungl Fysiografiska Sällsk Lund Förhandlingar 16, 45-56.

Migula, W. (1894). Über ein neues system der bakterien. Arb Bakteriol Inst Karlsruhe 1, 235-238.
Minnikin, D. E., O’Donnell, A. G., Goodfellow, M., Alderson, G., Athalye, M., Schaal, A. \& Parlett, J. H. (1984). An integrated procedure for the extraction of bacterial isoprenoid quinones and polar lipids. J Microbiol Methods 2, 233-241.

Nakagawa, Y., Sakane, T. \& Yokota, A. (1996). Emendation of the genus Planococcus and transfer of Flavobacterium okeanokoites Zobell and Upham 1944 to the genus Planococcus as Planococcus okeanokoites comb. nov. Int J Syst Bacteriol 46, 866-870.

Reddy, G. S. N., Prakash, J. S. S., Vairamani, M., Prabhakar, S., Matsumoto, G. I. \& Shivaji, S. (2002). Planococcus antarcticus and Planococcus psychrophilus spp. nov. isolated from cyanobacterial mat samples collected from ponds in Antarctica. Extremophiles 6, 253-261.

Schleifer, K. H. \& Kandler, O. (1972). Peptidoglycan types of bacterial cell walls and their taxonomic implications. Bacteriol Rev 36, 407-477.

Tamaoka, J. \& Komagata, K. (1984). Determination of DNA base composition by reverse-phase high-performance liquid chromatography. FEMS Microbiol Lett 25, 125-128.

Wayne, L. G., Brenner, D. J., Colwell, R. R. \& 9 other authors (1987). International Committee on Systematic Bacteriology. Report of the ad hoc committee on reconciliation of approaches to bacterial systematics. Int J Syst Bacteriol 37, 463-464.

Yoon, J.-H., Kim, H., Kim, S.-B., Kim, H.-J., Kim, W. Y., Lee, S. T., Goodfellow, M. \& Park, Y.-H. (1996). Identification of Saccharomonospora strains by the use of genomic DNA fragments and rRNA gene probes. Int J Syst Bacteriol 46, 502-505.

Yoon, J.-H., Lee, S. T., Kim, S.-B., Goodfellow, M. \& Park, Y.-H. (1997). Inter- and intraspecific genetic analysis of the genus Saccharomonospora with $16 \mathrm{~S}$ to $23 \mathrm{~S}$ ribosomal DNA (rDNA) and $23 \mathrm{~S}$ to $5 \mathrm{~S}$ rDNA internally transcribed spacer sequences. Int J Syst Bacteriol 47, 661-669.

Yoon, J.-H., Lee, S. T. \& Park, Y.-H. (1998). Inter- and intraspecific phylogenetic analysis of the genus Nocardioides and related taxa based on 16S rDNA sequences. Int J Syst Bacteriol 48, 187-194.

Yoon, J.-H., Kang, S.-S., Lee, K.-C., Lee, E. S., Kho, Y. H., Kang, K. H. \& Park, Y.-H. (2001). Planomicrobium koreense gen. nov., sp. nov., a bacterium isolated from the Korean traditional fermented seafood jeotgal, and transfer of Planococcus okeanokoites (Nakagawa et al. 1996) and Planococcus momeekinii (Junge et al. 1998) to the genus Planomicrobium. Int J Syst Evol Microbiol 51, 1511-1520.

Yoon, J.-H., Kim, I.-G., Shin, D.-Y., Kang, K. H. \& Park, Y.-H. (2003). Microbulbifer salipaludis sp. nov., a moderate halophile isolated from a Korean salt marsh. Int J Syst Evol Microbiol 53, 53-57. 